5 Najafzadeh TM, Dumars KW. Duplication of distal 11q and $22 \mathrm{p}$-occurrence in two unrelated families. $A m J$ Med Genet $1981 ; 8: 341-7$.

6 Van Dyke DL, Weiss L, Logan M, Pai GS. The origin and behavior of two isodicentric bisatellited chromosomes. Am J Hum Genet 1977;29:294-300.

7 Guanti G. The aetiology of the cat eye syndrome reconsidered.J Med Genet $1981 ; 18: 108-18$.

8 Goodpasture C, Bloom SE. Visualization of nucleolar organizer regions in mammalian chromosomes using silver-staining. Chromosoma 1975;53:37-50.
9 Petit P, Godart S, Fryns JP. Silver staining of the supernumerary chromosome in the cat-eye syndrome. Ann Genet (Paris) 1980;23:114-6.

Correspondence and requests for reprints to $\mathrm{Dr}$ G N Wilson, Section of Pediatric Genetics, C S Mott Children's Hospital, K2015 Holden, Box 007, Ann Arbor, Michigan 48109, USA.

\title{
Triploidy with cyclopia and identical HLA alleles in the parents
}

\author{
J C LAMBERT, P PHILIP, G CHARPENTIER, M FERRARI, \\ M DONZEAU, AND N AYRAUD
}

From Laboratoire d'Histologie, Embryologie, et Cytogénétique, INSERM U 210, Faculté de Médecine, Nice, France.

SUMMARY A 22-week pregnancy was terminated after discovery of serious echographic abnormalities. Fetal examination showed cyclopia, sacral meningocele, and syndactyly. The karyotype was $69, \mathrm{XXX}$. The parents had identical HLA alleles A1, A2, and Bw21. The mechanism of the triploidy was determined by chromosome marker analysis to be digyny. The association of triploidy with holoprosencephaly and the parents' identical immunological status are discussed.

Triploidy is a common chromosomal abnormality, occurring in about $2 \%$ of human conceptuses. As a general rule these abnormal embryos are spontaneously aborted early in gestation. ${ }^{1}$ The present article reports a case of triploidy which is unusual for the following reasons: the survival of the fetus to 22 weeks; the rare association of triploidy with holoprosencephaly; and the discovery of identical HLA $-A$ and $-B$ alleles in the parents.

\section{Case report}

A 22-week fetus was aborted abdominally. The 23year-old G2, P1 mother had had an apparently normal stillborn fetus 2 years earlier. This was followed by treatment for hyperthyroidism. The mother and her healthy 29-year-old husband were not consanguineous and the family history was unremarkable.

The second pregnancy proceeded normally until

Received for publication 11 May 1983.

Accepted for publication 16 May 1983. the 21 st week when uterine sonography revealed an increased cranial diameter for gestational age and absence of median echo as well as a caudal mass. Elective abortion was performed in the 22 nd week.

Examination of the female fetus confirmed the echographic diagnosis of sacral meningocele with hydrocephalus and revealed the presence of cyclopia (fig 1). The head had a single diamond-shaped orbit, surrounded by four rudimentary eyelids located in the middle of the face and containing a single eyeball. A fleshy supraorbital proboscis was present with a terminal dimple. The philtrum was absent and the mouth was small. There was complete syndactyly between fingers 3 and 4 of both hands.

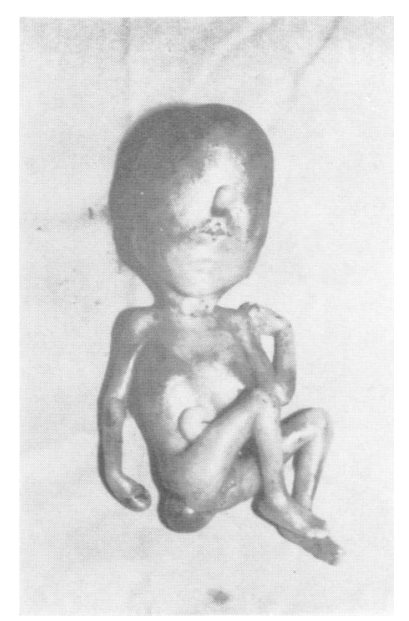

FIG 1 The fetus. 
At necropsy, an excess of cerebral fluid was noted and the forebrain was represented by a single spherical structure. The median sulcus was absent as were the corpus callosum, the septum pellucidum, the olfactory nerves, the optic chiasmata, and the pituitary gland. A single median ventricle was present. The eyeball contained two distinct lenses. Both adrenal glands were absent. Elsewhere there was normal development for gestational age. Histological examination of the gonads showed them to be ovaries. The placenta was normal.

The karyotype from skin fibroblasts was $69, \mathrm{XXX}$ in all cells examined (fig 2).

Parental HLA markers were examined in an attempt to explain the mechanism of the triploidy.
This revealed the surprising result of identical locus $\mathbb{D}$ A alleles (A1, A2) in both parents as well as one of $\underset{+}{\oplus}$ the locus B alleles (Bw21). The other locus B allele in both parents was also Bw21 or a rare one not? included in our battery. These tests were repeated to 0 eliminate the possibility of error. HLA alleles A1, 음 $A 2$, and Bw21 were subsequently detected in skin $\frac{\bar{N}}{\partial}$ fibroblasts from the fetus.

The mechanism of the triploidy was finally explained by study of chromosome markers. The $\vec{P}$


had a marker while those of the mother had none. $\overrightarrow{\vec{\omega}}$ In the fetus, only one of the three chromosomes $21 \stackrel{\mathrm{\omega}}{\mathrm{S}}$ had a marker (fig 3). The mechanism involved is therefore digyny.
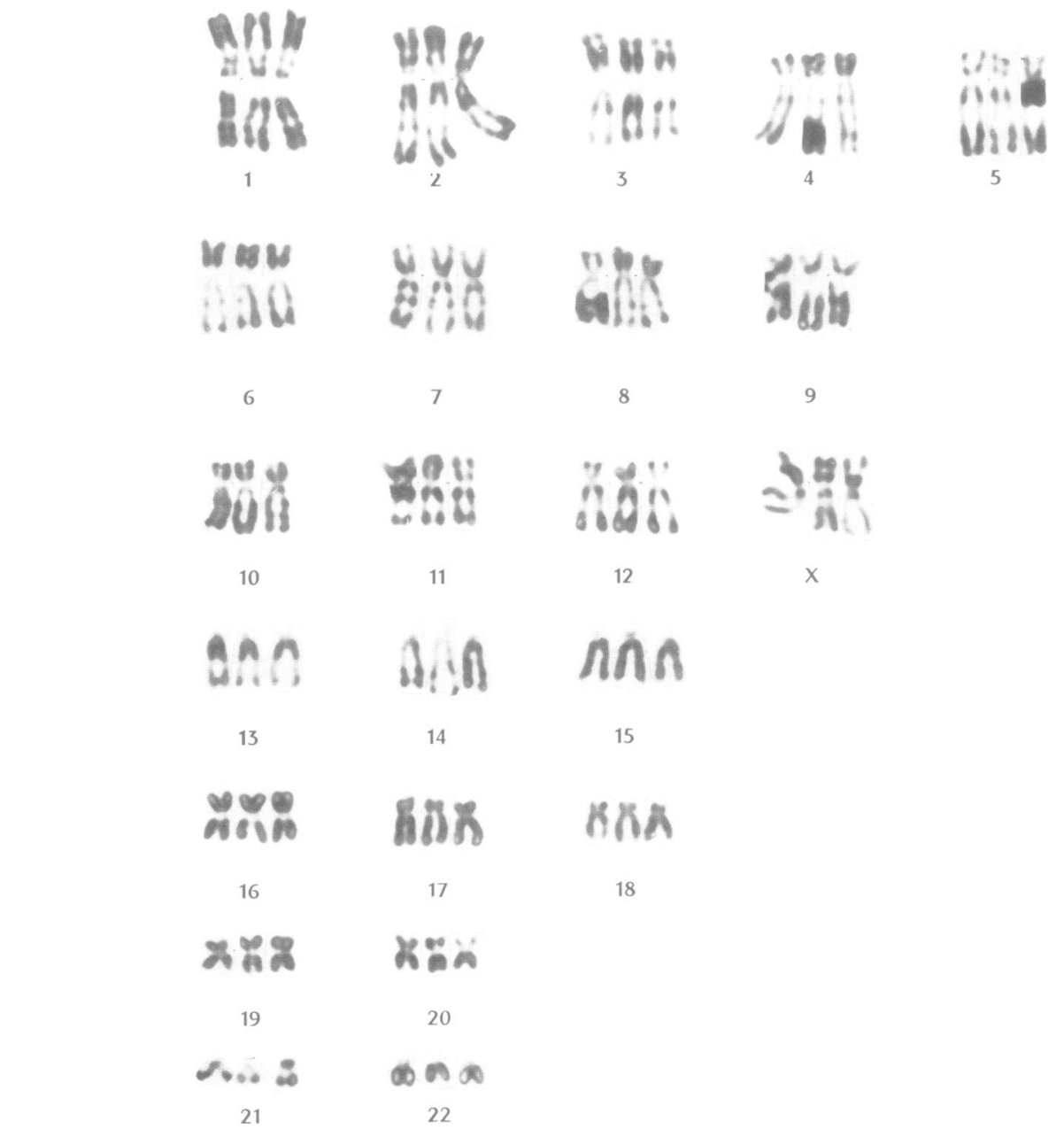

FIG 2 Karyotype of the fetus (RHG banding). 




FIG 3 Partial karyotype of the mother, fetus, and father ( $R H G$ banding).

\section{Discussion}

The present case is remarkable for the combination of the unusual phenotypic expression of the triploidy and the presence of identical HLA markers in the parents. Full triploidy is generally a chromosomal abnormality resulting in early spontaneous abortion. In some cases the pregnancy proceeds to near term and results in the birth of a malformed child who survives only a few days at most. ${ }^{2}$ This case can be considered to be in the latter group since the gestation proceeded until 22 weeks before therapeutic abortion.

The clinical picture of full triploid subjects is variable. ${ }^{34}$ This diversity of phenotypes is probably the result of the expression of recessive genes helped by the existence of three haploid complements. Only two cases of triploidy with holoprosencephaly have been reported. ${ }^{56}$ Detailed analysis of these cases led us to the conclusion that this association does not constitute a separate clinical entity as the other features of these cases are often seen in triploidy without holoprosencephaly (table). Thus, holoprosencephaly seems to be merely a rare occurrence in a chromosomal abnormality which is variable in its phenotypic expression.

The part played by the parents' immunological similarity may be discussed at three different levels: firstly, the mechanism of origin of the triploidy; secondly, the absence of classical hydatidiform changes; and, thirdly, the unusual survival of the fetus.

In their studies of spontaneous human abortions, Boué et $a l^{7}$ noted that HLA marker analysis of parents who had triploid abortuses showed an increased number of parents with two HLA alleles in common. They suggested that identical HLA markers in parents favour dispermy, since HLA antigens may play a role in the mechanism which inhibits penetration of the ovum by a second spermatozoa. This hypothesis is irrelevant in the present case since the mechanism here was digyny.

The association of triploidy with hydatidiform

TABLE Comparison of three cases of triploidy with holoprosencephaly and those without.

\begin{tabular}{|c|c|c|c|}
\hline \multicolumn{4}{|c|}{ Triploidy with holoprosencephaly } \\
\hline Age & $\begin{array}{l}22 \text { weeks } \\
\text { spontaneous abortion }\end{array}$ & $\begin{array}{l}22 \text { weeks } \\
\text { spontaneous abortion }\end{array}$ & $\begin{array}{l}22 \text { weeks } \\
\text { therapeutic abortion }\end{array}$ \\
\hline $\begin{array}{l}\text { Face } \\
\text { Other signs }\end{array}$ & $\begin{array}{l}\text { Cebocephaly } \\
\text { Syndactyly 3-4, } \\
\text { simian crease, } \\
\text { occipital meningocele }\end{array}$ & $\begin{array}{l}\text { Cyclopia } \\
\text { Syndactyly } 3-4, \\
\text { polycystic kidneys, } \\
\text { absence of thyroid } \\
\text { and adrenals }\end{array}$ & $\begin{array}{l}\text { Cyclopia } \\
\text { Syndactyly 3-4, } \\
\text { sacral meningocele, } \\
\text { absence of adrenals }\end{array}$ \\
\hline Karyotype & $69, \mathrm{XXX}$ & $69, X Y Y$ & $69, \mathrm{XXX}$ \\
\hline
\end{tabular}

General features in full triploidy

Large fontanelles

Hypertelorism

Microphthalmos

Colobomata of iris

Malformed auricles

High arched palate

Cleft lip and/or palate

Simian crease

$\begin{array}{llc}30 \% & \text { Syndactyly } & 60 \% \\ 40 \% & \text { Hypotonia } & 35 \% \\ 25 \% & \text { Meningomyelocele } & 25 \% \\ 25 \% & \text { Cardiac malformations } & 55 \% \\ 55 \% & \text { Urinary tract malformations } & 70 \% \\ 25 \% & \text { (especially cystic kidneys) } & \\ 40 \% & \text { Endocrine gland hypoplasia } & 45 \% \\ 40 \% & \text { Malformations of genitalia } & 69, \mathrm{XXY}\end{array}$


changes in the placenta has been recognised for many years, but the precise correlation between the origin of additional haploid complements and these changes has been made only recently: all paternally derived triploids are partial moles whereas only a few maternally derived triploids are molar. ${ }^{8}$ Our observation is not an exception to this general rule. In these conditions it is difficult to implicate the HLA system in the mechanism leading to the development of a partial hydatidiform mole in the presence of two paternal and one maternal set.

The survival or expulsion of an aneuploid fetus seems to depend on various factors, such as the existence of serious malformations which interrupt embryogenesis at an early stage ${ }^{1}$ or hormonal factors. In chromosomal abnormalities the placenta has varying degrees of defective endocrine function which results in embryonic death. ${ }^{9}$ Here it should be observed that the development of hydatidiform mole in triploid conceptuses does not change the gestational age of fetal death but favours the retention of the fetus after death. ${ }^{10}$ Another factor is maternal age, in that it is possible that older mothers are more tolerant of the aneuploid zygote. ${ }^{11} \mathrm{We}$ are thus led to consider the possibility that immunogenetic similarity between the aneuploid fetus and the mother may also favour the continuation of the pregnancy.

We thank Mrs A M Saunieres for technical assistance and P Brewer for help with translation.

\section{References}

1 Boué JG, Boué A. Chromosomal anomalies in early spontaneous abortion (their consequences on early embryogenesis and in vitro growth of embryonic cells). In: Gropp A, ed. Current topics in pathology. Developmental biology and pathology. Vol 62. Berlin, Heidelberg:? Springer, 1976:193-208.

2 de Grouchy J, Roubin M, Risse JC, Sarrut S. Enfant triploïde $(69, \mathrm{XXX)}$ ayant vécu neuf jours. Ann Geneto (Paris) 1974; 17:283-6.

3 David M, Chambon A, Laurent C, et al. La triploïdie $\frac{\bar{c}}{\bar{s}}$ chez l'enfant. I. Etude du phénotype. A propos d'une? observation de triploïdie en mosaïque $46, \mathrm{XX}, 69, \mathrm{XXY} \stackrel{\mathbb{\Omega}}{\Omega}$ Pédiatrie 1975;30:281-98.

4 Niebuhr E. Triploidy in man. Cytogenetical and clinical aspects. Hum Genet 1974;21:103-26.

5 Deligdisch L, Legum C, Peyser MR, Toaff R. Cyclopia associated with triploidy and hydatidiform mole: a case $\vec{\omega}$ report. Teratology 1978;18:257-62.

6 Emberger JM, Marty-Double C, Pincemin D, Caderas de Kerleau J. Holoprosencéphalie par triploïdie 69, XXXO chez un foetus de 5 mois. Ann Genet (Paris) 1976;19:191-3Nㅗ

7 Boué J, Couillin P, Boué A. Mechanisms of triploidy:Clin Genet 1981;19:493.

8 Jacobs PA, Szulman AE, Funkhouser J, Matsuura JS, Wilson CC. Human triploidy: relationship betweers parental origin of the additional haploid complement and development of partial hydatidiform mole. Ann Hum Genet $1982 ; 46: 223-31$.

9 Boué J, Morer I, Vignal P. Essai de définition d'urE coefficient de risque d'anomalie chromosomique eI début de grossesse. J Genet Hum 1980;28:149-53.

10 Szulman AE, Philippe E, Boué JG, Boué A. Humarco triploidy: association with partial hydatidiform mole and non molar conceptuses. Hum Pathol $1981 ; 12: 1016-81$ 1:

11 Aymé S, Lippman-Hand A. Maternal age effecto aneuploidy: does altered embryonic selection play a r Am J Hum Genet 1982;34:558-65.

Correspondence and requests for reprints to Dr $\mathrm{J}$ Lambert, Laboratoire d'Histologie, Embryologie, ę Cytogénétique, Faculté de Médecine, Chemin d $\vec{E}$ Vallombrose, 06000 Nice, France.

\title{
Concordant monozygotic twins with bilateral renal agenesis
}

\author{
J R W YATES*, G MORTIMER + , J M CONNOR*, AND JANET E DUKE $\dagger$ \\ *The Duncan Guthrie Institute of Medical Genetics, Yorkhill, Glasgow G3 8SJ; and \\ †the Glasgow Royal Maternity Hospital, Rottenrow, Glasgow G4 ONA.
}

SUMMARY We report the unique observation of monozygotic twins concordant for bilateral renal agenesis.

\section{Case report}

Both parents were 25 years of age and in good health. They were unrelated and there was no

Received for publication 1 June 1983. Accepted for publication 1 July 1983. family history of renal tract abnormalities. The mother's first pregnancy had resulted in a health male infant born by Caesarean section after failed forceps delivery. In this, her second pregnancyo twins were diagnosed by ultrasound at 15 week gestation and the decision was taken to deliver then by elective Caesarean section. She remained we throughout an uneventful pregnancy and there waso no history of exposure to drugs or other know $\bar{P}$ teratogens. A second ultrasound examination at 28 